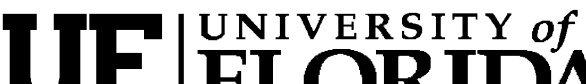 FLORIDA \\ IFAS Extension
}

\section{Thielaviopsis Trunk Rot of Palm 1}

Monica L. Elliott ${ }^{2}$

\section{Summary}

- Thielaviopsis trunk rot is caused by the fungus Thielaviopsis paradoxa.

- Due to this disease, the palm trunk either collapses on itself or the canopy suddenly falls off the trunk, both without warning. The palm canopy often appears healthy prior to collapse.

- Except for "stem bleeding," which is common in Cocos nucifera (coconut), there may be no symptoms prior to collapse of the palm.

- Only fresh trunk wounds will become infected by the fungus, so disease management includes limiting man-made wounds to the palm trunk.

- If the disease is detected early, cutting out the rotted, infested wood followed by spraying the wound site with a fungicide may be useful.

- There are no other methods to prevent or cure this disease. The palm should be removed immediately, and the diseased trunk portion destroyed but not recylced.

\section{Introduction}

Thielaviopsis paradoxa is a fungus that can infect any part of a palm, and so can cause numerous diseases. In Florida, the two most frequent (and usually lethal) Thielaviopsis diseases observed in the landscape and field nursery are a bud (heart) rot and trunk rot. Thielaviopsis bud rot is discussed at http://edis.ifas.ufl.edu/pp144.

\section{Pathogen and Hosts}

Thielaviopsis paradoxa is a fungus with many names. Its "asexual" stage name has changed from Thielaviopsis to Chalara and, more recently, back to Thielaviopsis. It is this stage that is most often encountered. The fungus produces two different types of asexual spores, endoconidia and chlamydospores. The latter will survive for long periods in the soil. The fungus also has a "sexual" stage name of Ceratocystis paradoxa. This stage is rarely observed in natural settings.

Thielaviopsis paradoxa appears to only be able to infect a palm when a fresh wound is present. Likewise, diseases caused by this fungus may progress more rapidly if the palm is stressed. Most infections occur in non-lignified or lightly lignified

1. This document is Fact Sheet PP-219, one of a series of the Plant Pathology Department, Florida Cooperative Extension Service, Institute of Food and Agricultural Sciences, University of Florida. Original publication date January 2006. Visit the EDIS Web Site at http://edis.ifas.ufl.edu.

2. M. L. Elliott, professor, Plant Pathology Department, Fort Lauderdale Research and Education Center--Ft. Lauderdale, FL; Florida Cooperative Extension Service, Institute of Food and Agricultural Sciences, University of Florida, Gainesville, FL.

The Institute of Food and Agricultural Sciences (IFAS) is an Equal Opportunity Institution authorized to provide research, educational information and other services only to individuals and institutions that function with non-discrimination with respect to race, creed, color, religion, age, disability, sex, sexual orientation, marital status, national origin, political opinions or affiliations. U.S. Department of Agriculture, Cooperative Extension Service, University of Florida, IFAS, Florida A. \& M. University Cooperative Extension Program, and Boards of County Commissioners Cooperating. Larry Arrington, Dean 
tissue. The fungus often produces volatile substances, specifically ethyl acetate and ethyl alcohol, which give the diseased tissue a fermented fruit odor.

While this fungus is found throughout the world, its host range is primarily restricted to monocot plants grown in warm climates. Besides palms, the fungus causes diseases of banana, pineapple and sugarcane. While the fungus has not been reported on every palm species grown in the landscape, all palm species are considered potential hosts for this fungus.

\section{Symptoms}

Unfortunately, there often are no visible indications that a palm has Thielaviopsis trunk rot until either the trunk collapses on itself (Figures 1 and 2 ) or the canopy suddenly falls off the trunk (Figure 3). The canopy often appears normal and healthy. Thus, there are no symptoms that can be used to predict which palms are infected and which ones are not. In most cases, the trunk rot is occurring in the upper half of the trunk. This may occur because the number of lignified fibers are greatest in the lower trunk and least in the upper trunk. As indicated previously, this fungus prefers to rot non-lignified or lightly lignified plant tissue.

In the situation where the canopy falls off the trunk, the rot is occurring below the bud at the base of the canopy in the woody tissue. This is also an area with little, if any, lignified plant tissue. When the trunk rot is further down the trunk, the fungus has rotted the trunk tissue until the palm can no longer structurally support itself. Examination of a cross-section through a diseased trunk illustrates that the rot is located only on one side of the trunk (Figures 4 and 5). This is in contrast to Ganoderma butt rot, in which the fungus is at the trunk base and rots from the center of the trunk to the outside.

Ganoderma butt rot is discussed at http://edis.ifas.ufl.edu/pp100.

"Stem bleeding" is a common symptom of Thielaviopsis trunk rot observed on Cocos nucifera (coconut). This stem bleeding is a reddish-brown stain that runs down the trunk from the point of infection (Figure 6). Since any trunk wound may result in stem bleeding, close examination of the

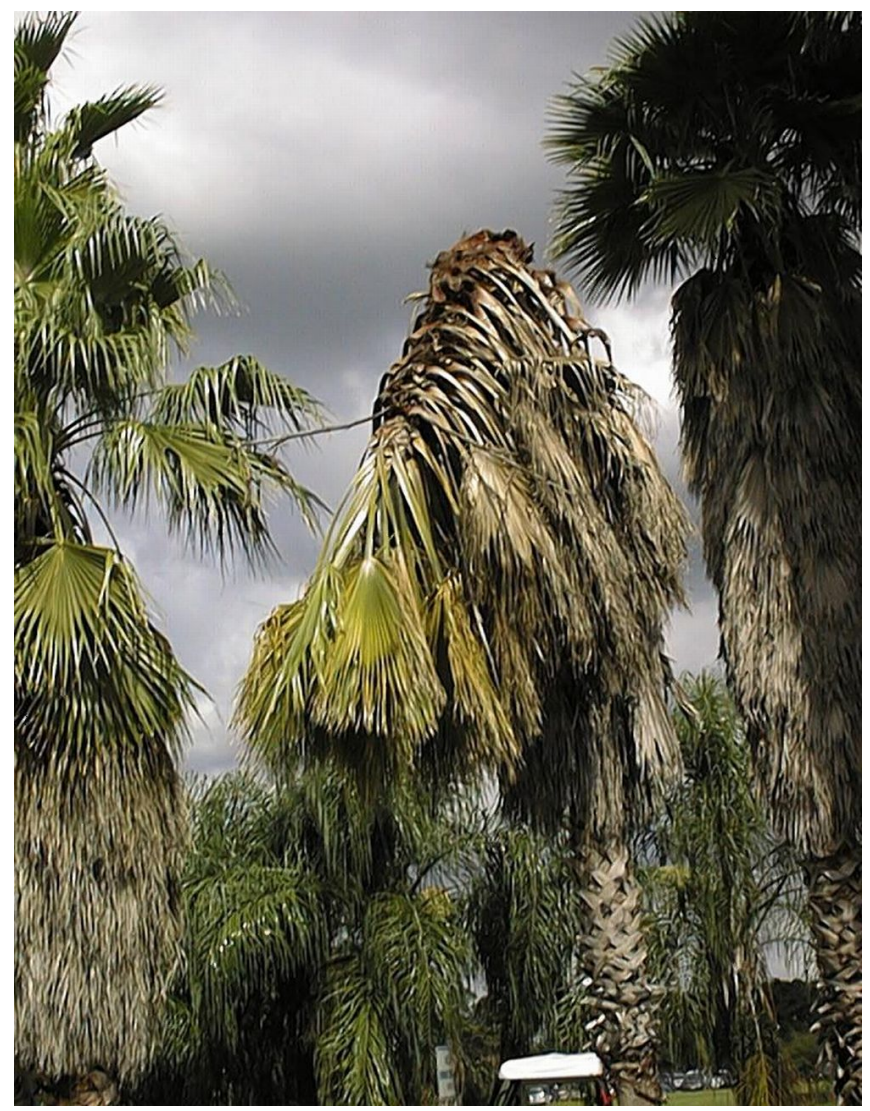

Figure 1. Washingtonia robusta with trunk collapsed on itself due to Thielaviopsis trunk rot. Credits: F.W. Howard

point of infection is required. If the stem bleeding is due to Thielaviopsis paradoxa and the disease has progressed significantly, the tissue immediately surrounding the wound (infection point) will be quite soft in comparison to surrounding trunk tissue. Palms other than coconuts, especially those with a smooth trunk, may also exhibit stem bleeding, but it seems to be most common in coconut. Eventually, the trunk will collapse on itself at the point of infection.

\section{Diagnosis}

The exact diagnosis of this disease is based on identification of the fungal pathogen from the diseased trunk tissue. It is usually not possible to determine the pathogen without examining the fungal spores. These may be examined directly on the plant tissue, if spores are being produced. Isolation of the pathogen can be made on artificial media, and this growth then observed for spores.

Note that trunk tissue will be required for fungal isolation and identification. The leading edge of the rotted trunk tissue is the best material for success in 


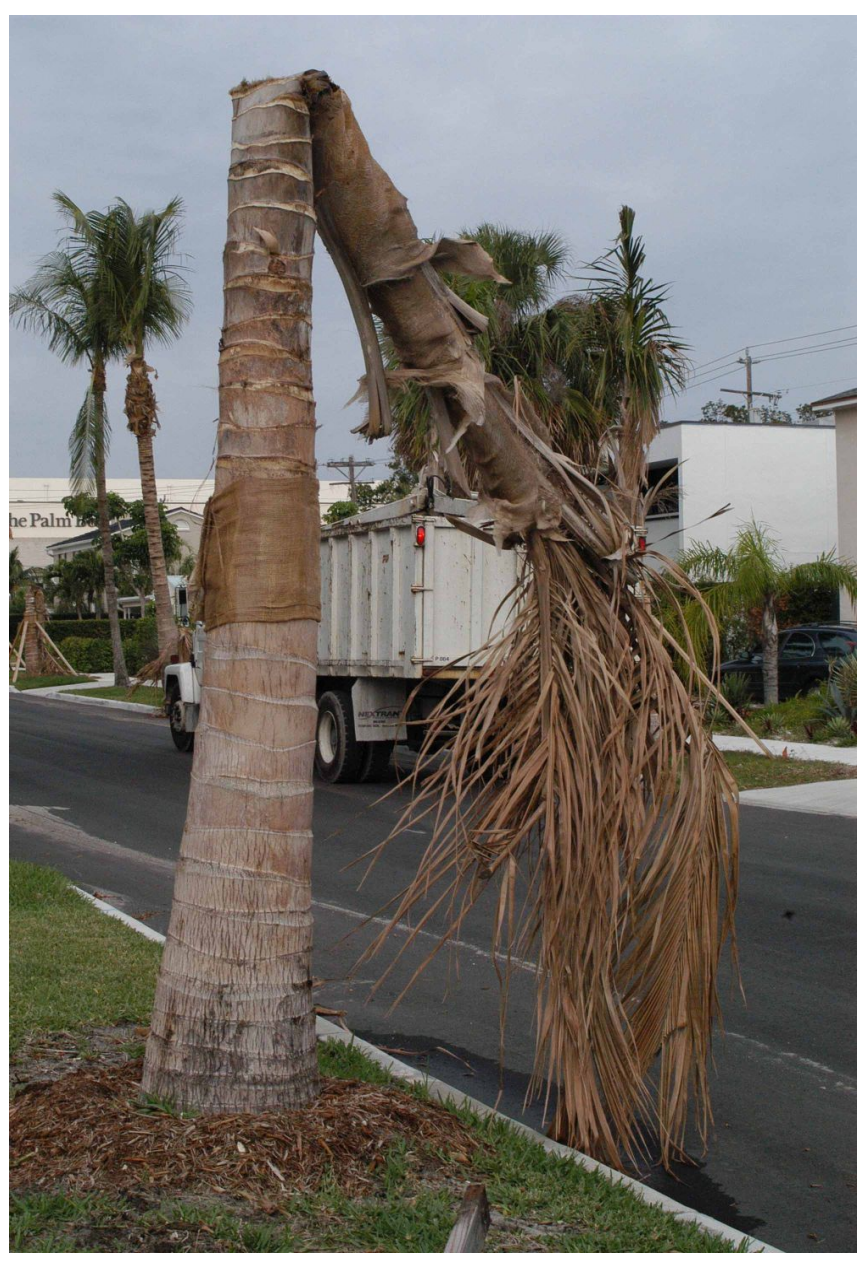

Figure 2. Cocos nucifera trunk collapsed upon itself due to Thielaviopsis trunk rot. Credits: M.L. Elliott

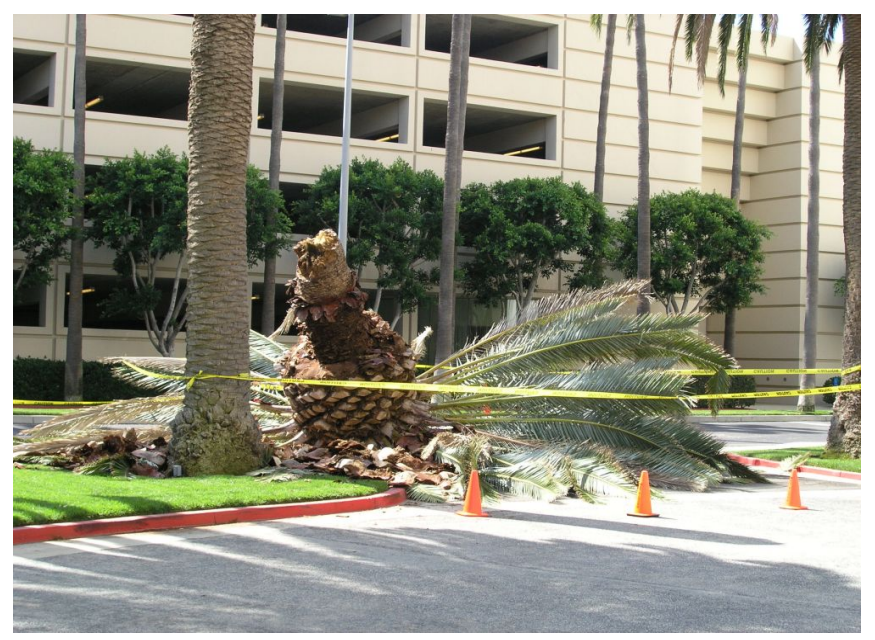

Figure 3. The canopy of this Phoenix canariensis fell off of the trunk due to Thielaviopsis trunk rot. Credits: $\mathrm{H}$.

Donselman

this endeavor. Older, rotted trunk tissue is likely to have secondary fungi and bacteria present which complicate, and sometimes prevent, the isolation of Thielaviopsis paradoxa.

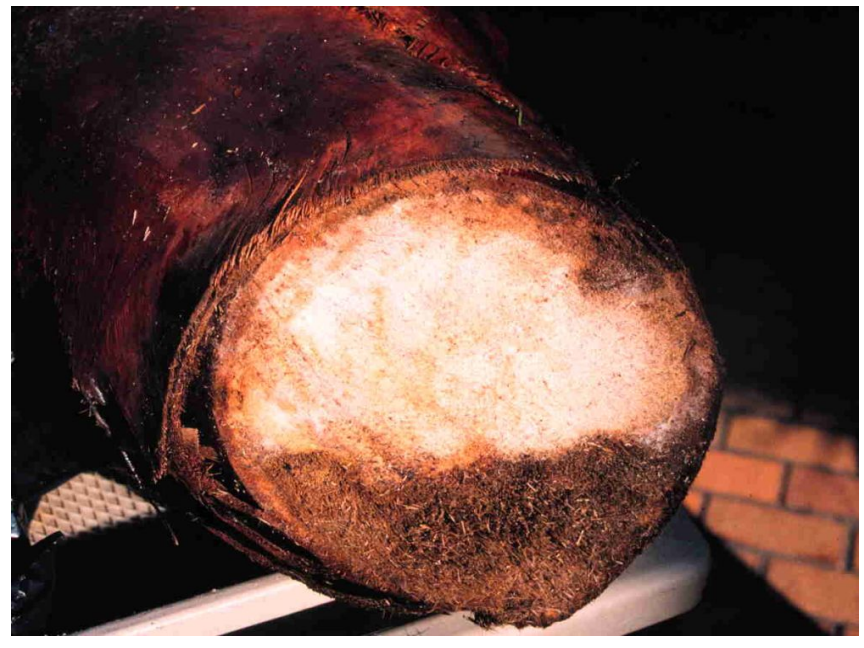

Figure 4. Cross-section of Washingtonia robusta trunk illustrating that the rot caused by Thielaviopsis paradoxa occurs on only one side of the trunk and moves from the outside to the inside of the trunk. Credits: M.L. Elliott

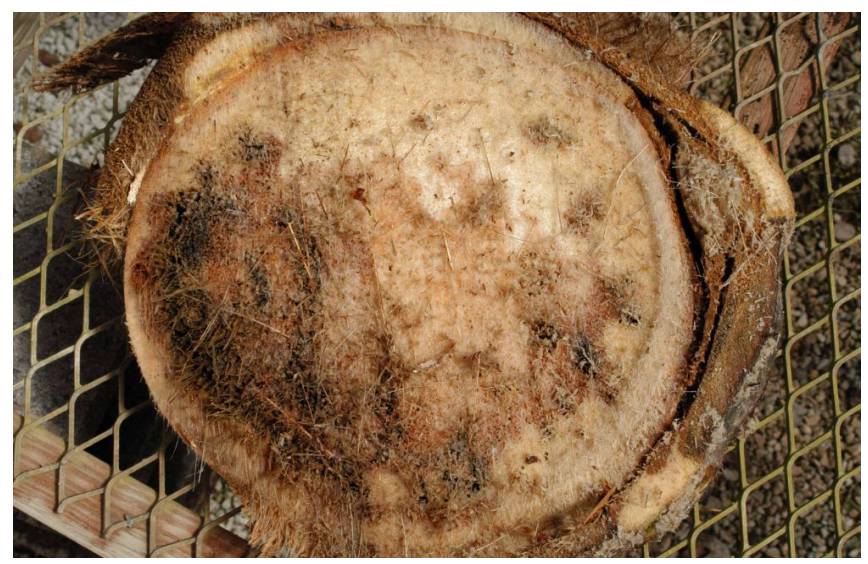

Figure 5. Cross-section of Cocos nucifera trunk illustrating that the rot caused by Thielaviopsis paradoxa occurs on only one side of the trunk and moves from the outside to the inside of the trunk. Credits: M.L. Elliott

The Florida Extension Plant Disease Clinic (FEPDC) network is available for pathogen identification. Contact your local county Extension office or FEPDC for details on sample submission and cost of the laboratory diagnosis.

\section{Disease Management}

Thielaviopsis trunk rot usually occurs quite randomly, with only a few palms in the landscape being affected. However, there are situations where high numbers of palms in a single landscape can become diseased, for reasons that are not always clear. In all situations, there has to be a fresh wound to the palm. Wounds can occur naturally, such as trunk cracks due to excess water uptake. Insects 


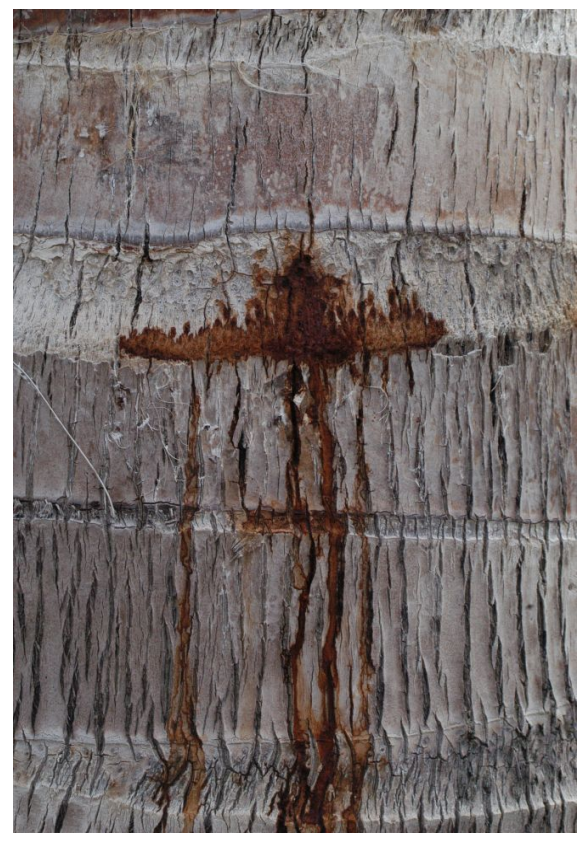

Figure 6. "Stem bleeding" on a Cocos nucifera due to infection from Thielaviopsis paradoxa. Credits: M.L. Elliott

(such as ambrosia beetles), birds (sapsuckers pounding on the trunk), rats, and other mammals can cause wounds. Blowing objects during a wind storm can strike a trunk and cause a fresh wound. Humans cause wounds with nails and climbing spikes, or during the digging and transplanting process.

Humans also create wounds when trimming leaves that are not yet dead. Leaf petioles are cut as close as possible to the trunk. If a leaf petiole has any green color associated with it, the leaf is still living. When that still living petiole is cut, a fresh wound is created that may be infected by the fungus. Trunks can be easily wounded during the trimming process with the careless use of the pruning tool. Pulling a leaf off the trunk, when the leaf petiole still has green tissue, can create a fresh wound.

The fungal pathogen can spread from palm to palm as follows. First, if spores are produced on diseased palm tissue, these spores can be moved by wind and water to fresh wounds. The spores may also be moved about by insects or rodents. Second, the chlamydospores are spores that can survive in the environment, especially soil, for long periods. Fresh wounds could become infected via contaminated soil.
Except for the stem bleeding, there are often no outwardly visible symptoms that indicate which palm in the landscape or field nursery has Thielaviopsis trunk rot. Thus, there are no proven strategies for preventing this disease. Once the palm has collapsed, remove it immediately as it is a source of fungal spores.

If one does observe the initial stages of the trunk rot, such as the stem bleeding, it would be useful to cut out the area of rotted wood (if it is not too large a trunk area) and spray the wound thoroughly with a fungicide labeled for Thielaviopsis diseases. Examples include, but are not limited to, products with the active ingredients thiophanate methyl or fludioxonil. The goal is to prevent the fungus from infecting the fresh wound made when you cut out the infested, rotted wood. All tools used to remove the rotted wood must be cleaned with a disinfectant.

Examples of disinfectants include: 1) $25 \%$ chlorine bleach (3 parts water and 1 part bleach); 2) $25 \%$ pine oil cleaner ( 3 parts water and 1 part pine oil cleaner); 3) 50\% rubbing alcohol (70\% isopropyl; equal parts alcohol and water); 4) 50\% denatured ethanol (95\%; equal parts alcohol and water); 5) $5 \%$ quatenary ammonium salts. Soak tools for 10 minutes and rinse in clean water. For chain saws, soak chain and bar separately.

Diseased trunk material should be destroyed and should not be recycled in the landscape. Chipping and then spreading the infested material in the landscape could spread the fungus to healthy palms. If the trunk is chipped, it should be placed in a properly constructed and monitored compost heap, or taken to a landfill or incinerator.

\section{Selected References}

Garofalo, J. F., and R. T. McMillan. 2004. Thielaviopsis diseases of palms. Proceedings of the Florida State Horticultural Society 117:324-325.

Paulin-Mahady, A. F., T. C. Harrington, and D. McNew. 2002. Phylogenetic and taxonomic evaluation of Chalara, Chalaropsis, and Thielaviopsis anamorphs associataed with Ceratocystis. Mycologia 94:62-72. 
Simone, G. W. 2004. Thielaviopsis diseases. Pages 37-38 in: Compendium of Ornamental Palm Diseases and Disorders. M. L. Elliott, T. K. Broschat, J. Y. Uchida, and G. W. Simone, eds. American Phytopathological Society, St.

Paul, MN.

Wingfield, M. J., K. A. Seifert, and J. F. Webber, eds. 1993. Ceratocystis and Ophiostoma:

Taxonomy, Ecology, and Pathogenicity. American Phytopathological Society, St. Paul, MN. 